\title{
DISCOURSES ON DEMOCRACY WITHIN DEBATES ON STATE-ISLAM RELATIONS IN INDONESIA
}

\author{
Arskal Salim \\ UIN Syarif Hidayatullah, Jakarta, Indonesia
}

\begin{abstract}
This study discusses the discourse on democracy within the context of the larger debate on Islam-state relations in Indonesia and correlates the religious approach with theories of democracy. It begins with a brief description of types of democracy formulated by political scientists in order to help us classify the Islamic groups' efforts in the process of democratization in Indonesia. This is followed by an exploration of these groups' views of democracy and their classification on the basis of their religious approach. The study considers both the debate about Islam-state relations and democracy as a competitive process over the interpretation of the predominant Islamic doctrine among the silent majority of the people. This study will also explore the role which Islam should play in the process of democratization. I will argue that the compatibility of Islam with democracy and democratization in the modern sense depends on the identification of universal values.
\end{abstract}

Keywords: Islam, democracy, shura, >hari $\rightarrow$ h.

\section{Introduction}

The emergence of Islam or "Islamization" in Indonesian politics during the 1990s has invited much criticism. This criticism relates not only to the problematic relationship between Islam and the state, but also to the discourse of democracy. One example of how the state has become connected with the deepening Islamization of Indonesia is the so-called "politics of accommodation". ${ }^{1}$ The most vocal, trenchant

\footnotetext{
${ }^{1}$ Realizing that political Islam was no longer a threat, the New Order regime began to treat it sympathetically by implementing a number of policies thought to agree with Islamic socio-cultural and political interests - e.g., the passing of the Religious Court
} 
criticism of the politics of accommodation has come from Abdurrahman Wahid, the former of chairman of the rural-based Islamic organization called Nahdatul Ulama (NU) and the former president of Indonesia.

Bahtiar Effendy recorded that according to Abdurrahman Wahid, "The state, to some extent, exacerbates these tendencies by involving itself in issues related to religious affairs, especially those which concern the interest of the Islamic majority." For Wahid, the ramifications of these practices could be very damaging. At stake are the principles of pluralism and national integration. Elaborating on this alarming possibility, he said:

Other than representing a discriminatory move toward religions adhered to by the minority [groups], the excessive intervention [of the state in religion] could eventually weaken the integration of the nation. Indonesia is not a theocratic state. Accordingly, the ruling government must set clear limits in administrating and protecting religious life. The essential meaning of democracy is to protect and defend the rights of minority. If for some reason the state or government is more concerned with the interest of a certain religion, or only accepting the truth from a certain religion, it suggests that the state is leaning toward sectarianism. $^{2}$

This description shows us that Wahid's rationale was based on democratic pillars (such as the principle of pluralism and the protection of minority rights).

Amien Rais, the former chairman of People's Consultative Assembly, expressed a view that differed from Wahid's conception of democracy and democratization. He said that the political struggle of Islamic groups to build a civil society should be democratic. In his opinion, "The essential meaning of democracy is to provide the sovereignty for the people, and their aspirations should be manifested

law (1989), the founding of ICMI (1990), the compilation of Islamic law (1991), the issuance of the Joint Ministerial Decree on the guidance of zakat administrator (BAZIS), the holding of an Islamic cultural festival (1991), the establishment of the Islamic Bank (1992), and the annulment of the national lottery (1993). Cf. Bahtiar Effendy, "Islam and the State: The Transformation of Islamic Political Ideas and Practices in Indonesia," Ph.D. Dissertation. The Ohio State University, 1994.

2 Effendy, "Islam and the State," pp. 359-360. 
both at the level of the executive and at the level of the legislative." 3 Rais regretted that while Muslims formed the majority in Indonesia, they did not receive proportionate attention for their economic or political development in the last twenty-five years of the New Order. He added that it is necessary for Muslims as a majority in this country to be well represented at both the legislative and the executive. ${ }^{4}$

The illustration presented above shows clearly that there is no single view among Muslims regarding Islam-state relations and its relation to democracy and democratization. One view is that in order to create democracy, one must collaborate with the government and promote democratic rules from within for people's sovereignty and government accountability. Another view is that democracy begins with the strengthening of democratic attitudes at the grassroots level through the promotion of democratic principles like freedom of expression, equality before the law, egalitarianism, and inclusive participation.

The problem is how to explain the Islamic groups' activities within the process of democratization in Indonesia. Are their efforts consistent with the workings of democracy? Why do they differ in their commitments to democracy? What is their major difference? Is one group better than the other? Are there many ways to build a democracy?

Few studies have been concerned with these themes. The following scholars have conducted research on either Islam-state or Islam-democracy relations in Indonesia: Bahtiar Effendy, ${ }^{5}$ Robert Hefner, ${ }^{6}$ Douglas Ramage, ${ }^{7}$ Martin van Bruinessen, ${ }^{8}$ and Masykuri

\footnotetext{
3 See his interviews "Representasi Umat Harus Diperjuangkan" in Arief Affandi, Islam Demokrasi Atas Bawah (Yogjakarta: Pustaka Pelajar, 1996), p. 122.

${ }^{4}$ Affandi, Islam Demokrasi Atas Bawah, p. 124-125.

5 Effendy, "Islam and the State,". Although this study describes Islam-state relations since pre-Indonesian independence, it does not focus on democracy or democratization. The main focus of this study is the explanation of some sociopolitical factors, which transformed the political attitudes of the New Order regime towards Islam.

${ }^{6}$ Robert W. Hefner, "Islamization and Democratization in Indonesia," in Robert W. Hefner and Patricia Horvatich (eds.), Politics and Religious Renewal in Muslim Southeast Asia (Honolulu: University of Hawaii Press, 1997). This article specifically deals with ICMI efforts on democratization in Indonesia.
} 
Abdillah. ${ }^{9}$ However, none of these studies correlates the theories of democracy with religious interpretations (particularly to the issue of state-Islam relations), as expressed by the two major sides among Islamic groups. Although the polemic ${ }^{10}$ in Indonesian newspapers between May and June 1995 on state-Islam relations correlated to some extent the debate on Islam-state relations (particularly between Gus Dur and Amien Rais) with the discourse on democracy, it cannot be substitute for a comprehensive study.

This study not only discusses the discourse on democracy within the larger debate on Islam-state relations in Indonesia, but also correlates the religious approach with the theories of democracy. For the purpose of this study, I will describe briefly the types of democracy formulated by some political scientists. This will help us classify the Islamic groups' efforts in the process of democratization in Indonesia. I will then probe into these groups' views of democracy and democratization and their classification, depending on their religious approach. Since Islamic doctrines may be said to support the most varied of political outlooks, including democracy, ${ }^{11}$ this study will

\footnotetext{
7 Douglas Ramage, Politics in Indonesia: Democracy, Islam and the Ideology of Tolerance, (London and New York: Routledge, 1995). Ramage discusses both ICMI's and Abdurrahman Wahid's political concepts of democracy and democratization. However, he concentrates on Pancasila as a Indonesian state ideology. Likewise, he does not try to correlate their political concepts of democracy and democratization with their respective religious approaches.
}

8 M. van Bruinessen, "State-Islam Relations in contemporary Indonesia; 1915-1990," in C. van Dijk and A.H. de Groot (eds.), State and Islam (Leiden: Research School CNWS, 1995). This article briefly portrays Islam-state relations in Indonesia from an historical perspective. Instead of focusing on debate on political thoughts, it merely deals with institutional relations like shari'a-state relations and Muslim partiesgovernment relations.

${ }^{9}$ Masykuri Abdillah, Responses of Indonesian Muslim Intellectuals to the Concept of Democracy (Hamburg: Abera Network Austronesia, 1997). This book emphasizes the theological perspective, describing Muslim intellectuals' doctrinal responses to democratic ideas. However, Abdillah does not sketch empirically the debates on Islam-state relations in Indonesia in the light of the theories of democracy.

10 The polemic initially triggered by Arief Affandi's article in Jawa Pos Daily involved twelve participants and is documented in Arief Affandi, Islam Demokrasi Atas Bawah: Polemik. Strategi Perjuangan Umat Model Gus Dur dan Amien Rais (Yogjakarta: Pustaka Pelajar, 1996).

${ }^{11}$ John L. Esposito acknowledged this point. He said, "History has shown that nations and religious traditions are capable of having multiple and major ideological 
consider both the debate on Islam-state relations and their respective commitment to democracy as a competitive process over the interpretation of the predominant Islamic doctrine among the silent majority of the people. The challenge to Islamic doctrine in Indonesia had already appeared in early the 20th century, well before independence.

This study will also explore the role which Islam should play in the process of democratization. This role depends on what kind of Islam is compatible with democracy and democratization. I will argue that the compatibility of Islam with democracy and democratization in the modern sense depends on the identification with universal values (human rights, non-discrimination, and inclusion).

\section{The Types of Democracy}

Juan J. Linz and Alfred Stepan explained that, attitudinally, democracy became "the only game in town", when the overwhelming majority of people believe that any further political change must emerge from within the parameters of democratic formulas. ${ }^{12}$

The question is, What precisely are the parameters of democratic formulas? Are democratic procedures the only parameters, as they claim? Are democratic principles also parameters? Since political scientists like Linz and Stepan do not appear to regard democratic principles as parameters, it is understandable that most young democratic states in the Third World tend to have a formal understanding of democracy, and thus pay little attention to the substantive meaning of democracy. This implies pseudo-democracy; a mere theatrical prop held up to reassure the world that the state continued to respect the basic rules of democracy.

interpretations or reorientations. indeed, democracy itself has had multiple meanings for different people at different times, from ancient to modern notions of democracy, from direct to indirect democracy, from majority rule to majority vote. The JudeoChristian tradition, which once supported political absolutism and divine right monarchies, was reinterpreted to accommodate the democratic ideal. Islam also lends itself to multiple interpretations; it has been used to support democracy and dictatorship, republicanism and monarchy. The twentieth century has witnessed both tendencies.” Cf. Esposito, The Islamic Threat: Myth or Reality? p. 242.

12 Juan J. Linz and Alfred Stepan, Problems of Democratic Transition and Consolidation: Southern Europe, South America and Post-Communist Europe (Baltimore and London: The Johns Hopkins University Press, 1996), p. 5. 
This kind of democratic parameters, I think, is no longer applicable, since it is generally felt that democratic parameters should include both democratic procedures and democratic principles. ${ }^{13}$ In the light of these distinguished parameters, the types of Third World democracy that Robert Pinkney presents appear quite relevant to this discussion. Pinkney introduced five types of democracy: radical democracy, guided democracy, liberal democracy, socialist democracy, and consociational democracy. ${ }^{14}$ I will refer to only two of them for the purpose of this study: radical and liberal, since both of these depict well the discourse of democracy in Indonesia.

Radical democracy. Society here is seen as an aggregate of individuals. Its objective is to enable these undifferentiated individuals to exercise their rights and protect their interests as active participants in the political arena. Citizens' rights are protected to the extent that all are equal before the law, but the protection of the individual against the power of the state is less loudly articulated than in a liberal democracy. As the will of the majority is supreme, the role of the state is to execute that will. "Even if the method of establishing the will of the majority is impeccably democratic, problems remain with regard to the positions of minorities, whether they are permanent minorities such as a particular ethnic or religious group." 15

Liberal democracy. This type of democracy recognizes society as an aggregate of diverse citizens acting as both individuals and members of groups. It aims at securing the representation of these individuals and groups, and protecting them from other groups and the state. Since liberal democracy considers society autonomous from the state, there is a clearer separation between the state and the society than in radical

13 I distinguished here the democratic parameters between their procedures and principles. The democratic procedures consist of institutions and rules like the parliament and the elections; while the democratic principles contain values and moral purposes (such equality, freedom of expression, and non-discrimination.

14 Pinkney's classification partly derived from the work of Dodd (1979) and Sklar (1983). After dismissing Dodd's "direct democracy" and Sklar's "participatory democracy", Pinkney offers a table of a fivefold classification and summarizes the features of each type of democracy in terms of objectives, conceptions of society, the role of the state, the political process, citizens rights, citizen participation, and the practical problems to which each type gives rise. Cf. Robert Pinkney, Democracy in the Third World, (Boulder, Colorado: Lynne Rienner Publishers, 1994).

15 Pinkney, Democracy in the Third World, p. 8. 
democracy. The role of the state in this type of democracy is not as executor of the general will or the will of majority, but rather as a referee to ensure the representation and protection of diverse interests. ${ }^{16}$

There are three obvious differences between these two types. First, liberal democracy places more emphasis than radical democracy on the protection of the rights and interests of individuals or groups. Second, society is more autonomous from the state in liberal democracy than in radical democracy. Third, the role of the state is more dominant in radical democracy than in liberal democracy. In sum, we may say that radical democracy is concentrated on the institutions or rules of democracy, while liberal democracy is more concentrated on the values or principles of democracy.

In Indonesia, the radical type of democracy reflects those who have a formal understanding of democracy, and I will call this type henceforth "formalist democracy". ${ }^{17}$ On the other hand, liberal democracy reflects those who understand democracy in terms of substantive principles. Accordingly, they should be called 'substantialist democracy'. This formalist-substantialist classification of democratic types may not be completely satisfactory, but a generalization is needed, given the intricate complexity of the Islamic democratic movement in Indonesia.

\section{Democracy and Islamic Interpretation Approach}

Since the concept of democracy actually stems from Western countries (outside Islam), there is no consensus among Muslims on how to respond to democracy. There have been at least three kinds of Muslim responses. First is "total rejection". Those who advocate this response believe that democracy has not originated from Islamic doctrine. This response is not really relevant to this study, as it does not welcome democracy. Only the other two will be discussed in the following section. The second response has been "critical acceptance", with the understanding that democracy does not contradict Islamic precepts, even the adherents of this view hold that some Islamic

\footnotetext{
16 Ibid., p. 10.

${ }^{17}$ Douglas M. Brown said that radical democracy, in terms of its theoretical derivation, is the radicalization of formal democracy. Cf. Douglas M. Brown, Towards a Radical Democracy: The Political Economy of the Budapest School (London: Unwin Hyman, 1988), p. 134.
} 
teachings, like shura>(consultation) and ijma $>$ (consensus), parallel democracy. The third is "complete acceptance", based on the realization that democracy in its entirety, as practised in the developed countries, is the only solution that ensures the welfare of all human beings - to use Huntington's phrase, "as the final form of human government". ${ }^{18}$

According to those who advocate critical acceptance, both Islamic doctrine and its history have provided the model of the state and the government based on democracy (that is, shurax consultation), ijma $>$ (consensus), and ijtiha (individual discretion). They further hold that shum $>$ as an Islamic concept and principle, does not differ from democracy. Sadek J. Sulaiman offered at least five similarities between shumand democracy. First, both shumat democracy arise from the central consideration that collective deliberation is more likely to lead to a fair and sound result for the social good than individual preference. Second, both concepts assume that a majority judgment tends to be more comprehensive and accurate than minority judgment. Third, shumat democracy proceed from the core idea that all people are equal in rights and responsibilities. Fourth, both concepts thereby commit to the rule of the people through application of the law, rather than the rule of individuals or family through autocratic decree. Fifth, both affirm that a more comprehensive fulfilment of the principles and values by which humanity prospers cannot be achieved in a nondemocratic, non-shumenvironment. ${ }^{19}$

"The logic of shurary Sulaiman explains, "like the logic of democracy, does not accept hereditary rule, for wisdom and competence are never the monopoly of any one individual or family." 20 Likewise, shumand democracy both reject government by force, for any rule sustained by coercion is illegitimate. Moreover, both forbid privileges - political, social, economic - claimed on the basis of tribal lineage or social prestige." 21 This kind of response seems to accept

\footnotetext{
18 Samuel P. Huntington, "Democracy for the Long Haul", Journal of Democracy, vol. 7, no. 2 (2 April 1996), p. 4.

${ }^{19}$ Sadek J. Sulaiman, "Democracy and Shura," in Charles Kurzman (ed.), Liberal Islam: a Sourcebook (New York: Oxford University Press, 1998), p. 98.

20 Ibid.

${ }^{21}$ Ibid.
} 
democracy because the latter has its roots in Islamic teachings, namely, shurar $>$ In other words, the more any system constitutionally, institutionally, and practically fulfils the principle of shurat, the more Islamic that system is.

Given the democratic types presented above, this kind of Islamic interpretation of democracy is closer to 'formalist democracy'. This is because it perceives shura $>$ and democracy as merely the best instruments to realize the principles of justice, equality, and human dignity in the collective socio-political experience. This may also be viewed from its emphasis on the majority as a key concept of democracy.

While in the preceding discussion we describe the characteristics of the critical acceptance response, which tends to be that of 'formalist democracy', the next response (complete acceptance) resembles "subtantialist democracy". According to this response, while Islamic doctrine provided a set of guidelines that accommodate democratic concepts like shura and ijma $\rightarrow$ it also offered features that might hinder democracy (that is, the primacy of shari $a b$ (Islamic law), the role of non-Muslims, and a tendency among the ulama Yreligious teachers) in Islamic political history to support authoritarian rule. For this reason, this response tends to accept democracy as it has been practised in Western democratic countries, rather than to recognize what has been called "Islamic democracy". The supporters of this response seem to pay more attention to the substantive principles of democracy. Because they believe that both the primacy of sharizh and the role of nonMuslims imply the negation of principles of democracy like equality before the law and freedom of expression, they may be categorized as a 'substantialist democracy'.

The above shows that both the critical and the complete acceptance of democracy acknowledge the compatibility of Islam with democracy. However, they differ on the priority of democracy. The critical acceptance of democracy focuses on the factors for democracy in Islamic precepts; while the complete acceptance response gives preference to the factors against democracy in Islamic doctrine. ${ }^{22}$

\footnotetext{
${ }^{22}$ Here I borrow "the factors within Islam that work for and against democracy" from Daniel E. Price, Islamic Political Culture, Democracy and Human Rights: A Comparative Study (Westport: Connecticut: Praeger, 1999), pp. 27-28.
} 
The description above, once again, clearly proves that the issue of the compatibility of Islam and democracy is one of contest between different Islamic approaches. This has been unavoidable in the modern political history of Indonesia. The following discussion about the debates on Islam-state relations in Indonesia should clarify this issue.

\section{Debates on Islam-State Relations in Indonesia}

In his article on state-Islam relations in Indonesia (1915-1990), Martin van Bruinessen did not categorize the various periods. This is perhaps because he focused more on the state and Islam with respect to institutional relations (Islam party-state relations, the council of ulama $>\mathrm{New}$ Order regime relations, the shari $>h$-state relations). ${ }^{23}$ However, it may be said that the debate on Islam-state relations went through at least three phases. The first phase was the preindependence period (1915-1944). The second is the period of consolidation of independence period (1945-1966). The third was the period of the New Order regime (1967-1998).

\section{The First Phase}

The problem of Islam-state relations initially arose in 1918 with a debate between some activists of Sarekat Islam (SI, Islamic Association) ${ }^{24}$ and Comite voor het Javaansche Nationalisme (The Committee for Javanese Nationalism). The latter criticized the former, insisting that politics and religion should be separated. Sarekat Islam activists rejected this opinion and argued that their movement was "Islamic nationalist". 25

This debate continued among Sarekat Islam members only because, since 1917, Marxist ideological thinking began to be felt in Sarekat Islam. Effendy pointed out that the introduction of Marxism in Sarekat Islam led to conflict and division within the leadership of the organization, creating two factions: an Islamic and a Marxist faction.

\footnotetext{
23 Van Bruinessen, "State-Islam Relations in contemporary Indonesia; 1915-1990,” pp. 96-112.

24 Sarekat Islam was the first Islamic organization formed by HOS Tjokroaminoto. This association was intended to oppose not only the Chinese domination but all forms of humiliation experienced by the native people; it responded to the Christianization promoted by missionaries and the exploitation of the Dutch colonialists. Cf. M. Rusli Karim, Perjalanan Partai Politik Indonesia (Jakarta: Rajawali Press, 1983), p. 19.

${ }^{25}$ Deliar Noer, Pengantar ke Pemikiran Politik (Jakarta: Rajawali Press, 1983), p. 186.
} 
This was especially true as both factions fought over control of the movement and the socialistic, revolutionary agenda. ${ }^{26}$ This division increased because of a theological-ideological rift. The leaders of the Islamic faction (Tjokroaminoto, Agus Salim, and Abdul Moeis) were "determined to stress Islam as the party's ideology, and move along the lines of the Middle Eastern pan-Islamism. In contrast, Semaun and Darsono (the leaders of the Marxist faction) "favoured the elimination of religion from practical politics." 27

The first serious debate on Islam-state relations took the form of a polemic between Soekarno (the leader of the Indonesian Nationalist Party at the time and later on the first president of Indonesia) and Mohammad Natsir (later the leader of the eminent Islamic party Masyumi) in the Panji Islam Journal [Banner of Islam] during the early 1940s. The polemic was focused on the issue of whether politics and religion should be separated or not. Although some authors characterized this as a polemic between Islam and nationalism, this study views it as a contest between different Islamic approaches of Muslims, implicating diverse perceptions of democracy. This polemic was deliberately long described here, because it had been perceived as a prototype of debates on Islam-state relations along Indonesian history later on.

The polemic originated with Soekarno's writings which appreciated the political changes in Turkey, notably those carried out by Mustafa Kemal, who abolished the Islamic caliphate in the 1920s. Although Soekarno claimed that his writings were simply "thought contributions", with special reference to the political changes in Turkey, it was believed that they showed how Soekarno's opinion agreed with Kemal's, or at least his concurrence with the developments in Turkey. This position generated critics like Natsir. ${ }^{28}$

By and large, all Soekarno favoured the separation of Islam from the state. Soekarno concurred with the separation of Islam and the state in Turkey because there was no consensus among the culama about the unity of religion and state. To support his understanding,

\footnotetext{
${ }^{26}$ Effendy, "Islam and the State," pp. 70-71.

27 Ibid., pp. 71-72.

${ }^{28}$ Noer, Pengantar ke Pemikiran Politik, pp. 187-205. See also Effendy, "Islam and the State, ” pp. 80-89.
} 
Soekarno referred to the opinion expressed by 'Ali>Abd al-Raæiq,$^{29}$ which according to Soekarno proved that "Muhłmmad was a Messenger of a religious calling, full of religiosity, untainted by a tendency to kingship or a call for worldly government, and also sterilized the intention to establish one caliphate or a head of Muslims community to conduct the state affairs." 30

Obviously, Soekarno disagreed with the idea of a close link between Islam and the state, especially in a country whose population is not uniformly Muslim. For him, the idea would only create a sense of discrimination, particularly among non-Muslims:

Thus reality shows us, that the principle of the unity of state and religion for a country, which its inhabitant is not $100 \%$ Muslim, could not be in line with [the principle of] democracy. In such a country, there are only two alternatives; there are only two choices; the unity of statereligion, but without democracy, or democracy, but the state is separated from religion., 31

This does not mean that Soekarno rejected Islamic doctrine. According to him, Islamic precepts may be included in government policies through parliamentary consensus. Since Muslims in Indonesia are a majority, "they would be able to set and determine the state agenda, resulting ultimately in the formulation of policy decisions imbued with Islamic values. Thus for Soekarno, the authenticity of an "Islamic state" was found not so much in the formal or legal adoption of Islam as the ideological and constitutional basis of the state, but more on the personal and mass manifestation of the "flame" and the "spirit" of Islam in the state policies."32

\footnotetext{
29 Ali Abd al-Raziq (Egypt, 1888-1966) was a judge and academic at the Al-Azhar University Cairo. In 1925, he published a book entitled al-Islam wa Usul al Hukm [Islam and the foundation of the government]. In this book, he argued that Islam does not specify any particular form of government, thus allowing Muslims to create democratic regimes. This reasoning may have been intended to undermine the Egyptian king's claim to the caliphate in the wake of the abolition of the Ottoman caliphate in 1924 by Mustafa Kemal.

30 Panji Islam, no. 20 (20 Mei 1940), as recorded in Noer, Pengantar ke Pemikiran Politik, pp. 189-190.

${ }^{31}$ Effendy, "Islam and the State," p. 81.

32 Ibid., p.82.
} 
Soekarno's view is based on his substantial interpretation of Islam and democracy. On the one hand, the permanent and universal nature of Islam, according to Soekarno, required its adherents to understand Islamic doctrines (especially those concerning issues of a societal nature) beyond their textual appearances. It is only through such endeavour that Muslims could grasp the "flame" or "spirit" of Islam in their encounters with modernity and the changing world. On the other hand, the unity of Islam and state in Indonesia, a multi-religious country, was viewed as undemocratic, because it implied the negation of democratic principles like equality before the law and freedom of expression. This admittedly proves that the substantial interpretation on Islam is analogous to 'substantialist democracy', as we have mentioned above.

What was the response to Soekarno's view? Contradicting Soekarno's ideas was Natsir, who promoted the idea of unity between religion and the state. Effendy summarized his views as follows:

Like many other Muslims, Natsir believed in the holistic nature of Islam. For him, Islam was not only ritual but comprised general principles for regulating relations between individual and society. Nonetheless, he was very much aware that the Qur'an and Muhammad traditions did not have "hands and legs" to make individuals faithful to the rules of Islam. Thus, in his view there was no doubt that Islam needed a viable instrument to make its injunctions operative, [that is, the state]...Given this perspective, Natsir was strongly of the opinion that Islam and the state were integrated religio-political entities. Natsir also recognized that Islam provided only general guidelines. A detailed prescription for how a state should be organized or structured rested in the ability of its leaders to conduct their own ijtihad (independent judgment) in order to meet the challenges of modernity, provided that such a task is carried out in a democratic manner. ${ }^{33}$

This clearly shows that Natsir's approach was very close to the formalistic interpretation, since he insisted on the traditionally close link between religion and the state. He expected the state to act as a means of support to Muslims in their application of Islamic precepts. Although Natsir's views also involved democratic argument, they were

33 Ibid., p. 86. 
typically (to use a term adopted for the purpose of this study) part of the critical acceptance of democracy. For Natsir, democracy should be defined as an anti-absolutist and anti-despotic doctrine. "Islam is nondemocracy $100 \%$ and also it is non-theocracy $100 \%$. Islam is Islam." "34 Although he acknowledged that there are some merits to democracy, democracy also had many weaknesses (e.g., the authoritarianism of a ruling party and nepotism). Because of his acceptance of democracy, he did not reject Soekarno's suggestion that Indonesian Muslims should dominate the parliament. However, he found this suggestion irrelevant, since Islam embraced the majority of Indonesian inhabitants. For Natsir, Indonesia was automatically a Muslim country. The suggestion, he thought, might be suitable for Muslims who governed in a non-Muslim, democratic country. 35

In spite of there being many differences and views on this issue, both approaches should be identified as Islamic, and hence perfectly valid, since Islam is a poly-interpretable religion. To use Effendy's phrase, "Even though at the most general level there is only one Islam, its form and expression vary from one Muslim individual to another." 36 Thus, one is not mistaken to say that the polemic was really a contest of Islamic approaches on Islam-state relations among Muslims. Unfortunately, during the next three decades (the second phase of the debate) the formalistic interpretation was perceived as the sole kind of Islamic approach, and hence became predominant, while the substantial interpretation was secular and then ignored.

\section{The Second Phase}

In the second phase of the debate, two events illustrate well the predominant formalistic interpretation of Muslims. The first happened at the meeting sessions preparing for Indonesian independence. ${ }^{37}$

\footnotetext{
${ }^{34}$ Noer, Pengantar ke Pemikiran Politik, pp. 201-202.

35 Ibid., pp. 201, 203.

${ }^{36}$ Effendy, "Islam and the State," p. 5.

${ }^{37}$ Close to the defeat of the Japanese in the World War II, the so-called the Dokuritsu Zyunbi Tyoosakai (also known as Badan Penyelidik Usaha-usaha Persiapan Kemerdekaan Indonesia, BPUPKI, or Investigatory Committee for the Efforts for the Preparation of Indonesian Independence) was set up. It consisted of both the supporters of Soekarno's Islamic approach and the supporters of Natsir's Islamic approach. Nonetheless, Natsir was not included in this committee, while Soekarno was a prominent figure in it. Based on my readings so far, historians and political observers have not explained why Natsir failed to join this committee. There was a fierce debate
} 
Beside the ideological and constitutional basis of the state, other relevant issues were included in this debate, such as whether or not the president should be Muslim; whether or not Islam ought to be the state religion; the necessity of having the state apparatus and agencies for the implementation of Islamic law; and Friday as a national Holiday. ${ }^{38}$ From the details of Boland's description of the discussions between the two blocs, it is apparent that both sides used democracy as an argument. ${ }^{39}$ However, it seemed that, in the terms used in this study, the substantialist bloc focused more on democracy than the formalist bloc.

The second event took place after the 1955 elections, with the Constituent Assembly (Dewan Konstituante) debates from 1956 to 1959. Several Islamic parties, like Masyumi, Nahdatul Ulama, PSII, and Perti, joined together to propose Islam as the basis of the Indonesian state, while non-Islamic parties such as PNI, PKI, Parkindo, Murba, and others were united in their rejection of Islam as the basis of Indonesia and promoted Pancasila ${ }^{40}$ as their basis. Instead of presenting arguments based on democracy, both sides in this debate tended to give more theological and philosophical reasons in their arguments, especially since both sides interpreted Pancasila in

in the committee on whether or not the new Republic of Indonesia should be founded on religion. The committee was divided into two blocs. On the one hand, there was the Islamic bloc, this time led by Ki Bagus Hadikusumo, Abdul Kahar Muzakkir, Abikusno Tjokrosujoso, and A. Wahid Hasyim (who basically argued that, given the preponderant position of Islam in Indonesia, the state should be based on Islam. On the other hand, there was the nationalist bloc (actually many of them were Muslim, some authors referred to them as Nationalist to distinguish them from the other bloc), led by Soekarno, Hatta and Supomo (who maintained that for the sake of unity the state should be "deconfessionalized", though by no means made irreligious in character). Effendy, "Islam and the State," pp. 91-92.

${ }^{38}$ Effendy, "Islam and the State," p. 93.

39 B.J. Boland, The Struggle of Islam in Modern Indonesia (The Hague: Martinus Nijhoff, 1982). Particularly Chapter I.

40 Pancasila is the Indonesian national ideology. In its simplest expression, Pancasila consists of the following five principles, which are included in the Preamble to the Indonesian Constitution of 1945: belief in God, a just and civilized humanitarianism, national unity, Indonesian democracy through consultation and consensus, and social justice. 
accordance with their ideological frameworks or their beliefs. ${ }^{41}$ In Adnan Buyung Nasution's assessment, "The debate was ideological, absolutist, and antagonistic, so that the parties did not come close to each other but on the contrary were driven farther apart". ${ }^{42}$

However, in Effendy's study, we find that although theological and philosophical arguments predominated the debate, both sides also presented democratic arguments. But, it seems immediately that the supporters of Pancasila gave more democratic arguments rather than Islamic parties. Effendy said that the Islamic parties proposed that Islam should be adopted as the state ideology based on: (1) the holistic nature of Islam; (2) the superiority of Islam over other worldly ideologies; and (3) the fact that Islam was adhered to by the majority of the country's population.

So long as Pancasila remained the state ideology, its supporters argued that it was (1) comprised of Islamic (though not only Islamic) elements, (2) a common platform, given the heterogeneity of Indonesia's religious community; (3) a viable ideological synthesis for those with different religious faiths; and (4) it would entail an image of constitutional discrimination if Islam become the basis of state. ${ }^{43}$

Despite this, it is interesting to note how the leaders of the Islamic parties responded to the concept of democracy, particularly on the question of whether or not Islam had a political system. Zaenal Abidin Ahmad, a Masyumi figure, argued that parliamentary democracy was the ideal Islamic political system, where the concept of shumaras fully integrated. ${ }^{44} \mathrm{Ma}$ 'arif further explained that all the Muslim leaders at the Constituent Assembly genuinely chose parliamentary democracy because it was the most compatible with the Islamic political ideal (although some were confused about how it related to the concept of God's sovereignty. 45 This shows that the idea of democracy among the

\footnotetext{
41 On this discussion, see A. Syafii Ma'arif, "Islam as the Basis of State: A Study of the Islamic Political Ideas as Reflected in the Constituent Assembly Debates in Indonesia," unpublished Ph.D. Dissertation, Illinois: University of Chicago, 1983.

42 Adnan Buyung Nasution, The Aspiration for Constitutional Government in Indonesia: A Socio-legal Study of the Indonesian Konstituante 1956-1959 Jakarta: Pustaka Sinar Harapan, n.y), p. 41.

${ }^{43}$ Effendy, "Islam and the State," pp. 118-121.

${ }^{44}$ Ma'arif, "Islam as the Basis of State", p. 252.

45 Ibid., p. 253.
} 
formalistic interpretation was not wholeheartedly understood; and this is why they could not accept it in its entirety.

A point needs to be mentioned about democratic performance and the appreciation of democracy in the late Soekarno's era. When President Soekarno introduced "Guided Democracy" replacing parliamentary democracy in 1959 and banned Masyumi in 1960, accusing it without proof of involvement in the rebellion, the leaders of Masyumi objected that this kind of democracy camouflaged authoritarian rule and therefore should be opposed. In this case, both the introduction of Guided Democracy and the liquidation of Masyumi by Soekarno had shifted positions. Now, Soekarno was pictured as authoritarian, while Masyumi, where Natsir was a leader, was viewed as pro-democracy. ${ }^{46}$ Nevertheless, Masyumi activists' understanding of democracy remained formal. This may be seen as merely criticism due to Masyumi's banning from the Indonesian political arena.

Perhaps, it suffices to say that in this phase the discourse on democracy failed to translate well into practice. Indeed, there had been a miscarriage of democracy. Both the parliamentary democracy endorsed by Masyumi and the guided democracy introduced by Soekarno failed to give birth to true democracy. This may be due, according to Fachry Aly, to the characteristics of democracy, which to most Indonesian people appeared foreign, abstract, elitist, and not deeply anchored in their tradition. ${ }^{47}$

However, Soekarno's dictatorship in the guided-democracy era generated tensions between the state and Islam. Accordingly, it inevitably facilitated the formation of the robust existence of exclusively political Islam, which has a formalistic interpretation of Islam as one of its characteristics. Meanwhile, since the formalistic interpretation was conceived as the sole kind of Islamic interpretation, the substantial interpretation gradually disappeared from Indonesian political arena. This condition lasted until the early years of the New Order regime (1966-1998).

\footnotetext{
46 Ibid., pp. 295-296.

47 Fachry Aly, "Keharusan Demokratisasi dalam Islam Indonesia", in Nasrullah A. Fauzi (ed.), ICMI: Antara Status Quo dan Demokratisasi (Bandung: Mizan, 1995), p. 134.
} 


\section{The Third Phase}

While the Soekarno's regime concentrated on political development through experimentation with guided democracy, the New Order regime under President Soeharto focused on economic development. Originally influenced by Rostow's notion of a series of developmental stages leading to an economic and social take-off, this regime put economic development above all other policy considerations. As Sirajuddin Syamsuddin argued, the agenda under the New Order has included the depoliticization of Islam, since a politically powerful Islam had been viewed as a potential obstruction to modernization. ${ }^{48}$

When the position of political Islam appeared to be worsening, particularly following the New Order's manoeuvre to restructure Indonesia's political format, many of its leaders became increasingly reactionary. Quoting Allan Samson, Effendy said that this signalled the inability of Islamic political activists to give an intelligent religiopolitical response to these challenges. Effendy also interpreted this persistently inflexible religio-political behavior as an indication of their inability to relinquish their formalistic and legalistic approach in politics. ${ }^{49}$

In the light of such a political setting, a few Muslims figures tried to revive the substantial interpretation of the relationship between Islam and the state. H.M.S. Mintaredja, chairman of Indonesian Muslim Party (Parmusi) thinks that Islam does not aim at the creation of an Islamic state. Syamsuddin says that, in Mintaredja's view, "the duty of Muslims is to struggle to create a true Muslim society, which should be distinguished from an Islamic state." 50 It seemed to Syamsuddin that the core of Mintaredja's idea is that there is to some extent a separation between state and "church" in Islam. ${ }^{51}$

According to Fachry Aly, however, Mintaredja's idea did not arise from theological reflections but rather due to the clashes between the state and Islam since Soekarno's era. Hence, it sounds more political.

\footnotetext{
48 Sirajuddin Syamsuddin, Religion and Politics in Islam: The Case of Mubammadiyah in Indonesian New Order, Ph.D. Dissertation. Los Angeles, University of California, 1991, p. 86.

${ }^{49}$ Effendy, "Islam and the State," pp. 145-146.

50 Syamsuddin, Religion and Politics in Islam, p. 97.

51 Ibid., p. 98.
} 
Aly asserted that Nurcholish Madjid, a prominent Indonesian Muslim intellectual, was the only pioneer who reintroduced the substantial interpretation. ${ }^{52}$

In view of the problematic of Indonesian Islam, which lies in the paradox between the defeat of politicized Islam and the rapid expansion of Islam, Madjid concluded that Islam's quantitative growth was not encouraged by the Islamic parties, since the Islamic parties have failed to build a positive and sympathetic image of Islam..$^{53}$ His slogan "Islam-Yes, Islamic Party-No" completely represented the substantial interpretation. Thus, Madjid's ideas, according to Muhammad Kamal Hassan, constitute "an attempt to reformulate in general terms the fundamental Islamic postulates regarding God, man and the physical world, and the manner of their relationships in the light of new political realities". ${ }^{44}$ What Madjid wanted to convey with these reinvigorative religio-political themes was not a proposal to revise the doctrine of Islam, but rather to urge Muslims adherents to rethink their understanding and interpretation of Islam.

While Madjid's theological concerns provoked many criticisms, it attracted some activists from some Islamic student organizations; such as HMI or PII particularly both in Jakarta and Yogjakarta, and later in the late 1980s were predominant in Muslim societies. Through lengthy discussion and intense discussions, it came out with a number of theology-politically conclusions. Effendy summarized their conclusions as below:

First, there is no clear-cut evidence that the Qur'a $\$$ and the Sunnah oblige Muslims to establish an Islamic state. Second, Islam does contain a set of socio-political principles. Even so, Islam is not an ideology. Third, Muslims understanding of Islam should not be confined to its formal and legal sense, since it is conceived as timeless

\footnotetext{
52 Aly, "Keharusan Demokratisasi", p. 138.

53 Nurcholish Madjid, "The Necessity of Renewing Islamic Thought and Reinvigorating Religious Understanding" in Charles Kurzman (ed.), Liberal Islam: A Sourcebook (New York: Oxford University Press, 1988), pp. 284-294.

${ }^{54}$ Muhammad Kamal Hassan, Muslim Intellectual Responses to "New Order" Modernization in Indonesia (Kuala Lumpur: Dewan Bahasa dan Pustaka Kementrian Pelajaran Malaysia, 1982), p. 89.
} 
and universal. Fourth, only Allah possesses the absolute truth. 55

Although democratic arguments are vague in the current theologypolitical thought, it clearly showed an accommodative tendency with respect to the regime's political policy. ${ }^{56}$ The regime welcomed this new dominant tendency, which it no longer perceived as a threat to its power. However, the lack of substantially democratic sentiment in this tendency implies to the "bewilderment", particularly in the face of political cooptation by the authoritarian state through the foundation of a regime-sponsored organization Ikatan Cendikiawan Muslim Indonesia (ICMI) or the Association of Indonesian Muslim Intellectuals. ${ }^{57}$

Unlike some Muslims who agreed with Madjid's idea without presenting substantially democratic arguments, Abdurrahman Wahid

${ }^{55}$ Effendy, "Islam and the State," pp. 151-152.

56 Madjid actually developed democratic arguments and stressed both their substantial and formal aspects, but some of his supporters seemed to focus on their formal meaning. This is perhaps due to Madjid's elaborations of democracy, which are long on the process of democratization. See his "Cita-cita Politik Kita", in Bosco Carvallo and Dasrizal (eds.), Aspirasi Umat Islam (Jakarta: Leppenas, 1983), pp. 16-21.

57 ICMI was founded on 7 December 1990. There are at least three opinions concerning the founding of ICMI. First, Robert Hefner expressed the lenient view. He shrewdly portrayed the president's public engagement with Islam as a "struggle to capture and direct the moral allegiance of urban middle class that has embraced this religion as their key source of ethical and spiritual guidance." See Robert W. Hefner, "Islam, State, and Civil Society: ICMI and the Struggle for the Indonesian Middle Class," Indonesia, no. 56 (1993), p. 2. The second opinion is the moderate view articulated by Kenneth George, who sees in ICMI's founding two aspects of the New Order regime. One, its founding indicates that state intrusion has formally embraced Muslim intellectuals, giving them the authority and influence ordinarily enjoyed by the ulamas, and other Muslim clerics in discussing social, cultural, and religious life. Two, the state inserted itself into the public sphere as a religious authority of sorts: it offered judgments upon and the legitimasization of the role of religion in civic affairs and the daily life of citizens. Cf. Kenneth George, "Designs on Indonesia's Muslim Communities", The Journal of Asian Studies, vol. 57, no. 3 (August 1998), p. 699. The third opinion was the fiercely critical view of William Liddle, who argued that ICMI is not an autonomous organization that represents the political interests of the Muslim community. Rather, it is a state corporatist organization, dominated by high officials beholden to President Soeharto and designed to advance his control of the political system through the 1997 elections and 1998, when the People's Consultative Assembly (Majelis Permusyawaratan Rakyat) were to have selected the country's president. Cf. William Liddle, "The Islamic Turn in Indonesia: A Political Explanation", Journal of Asian Studies, vol. 55, no. 3 (August 1996), p. 625. 
argued that Islam needed to accept plurality and to accommodate indigenous and local circumstances. This point allowed Wahid to advocate the notions of: (1) Islam as a complementary factor in Indonesia's socio-cultural and political life, and (2) the indigenisation or contextualization of Islam. ${ }^{58}$ The peculiarity of Wahid's notions laid in his regarding that the ideal form is not an Islamic society even less an Islamic state, but an Indonesian society where Muslims and nonMuslims share the same advantages. So, his main concern is actually about the equality of rights and obligations among Indonesia's existing socio-political communities - assuming that Pancasila is the nation's ideological compromise. This view is quite different from that of Muslims who think that the ideal Indonesian society is a society where Muslims dominate the political scene (for example, by having a right to the presidency), just because they are the majority. ${ }^{59}$

In the light of these divergences among the supporters of the substantial interpretation, it is understandable that many of them could accept to join ICMI. Yet, due to his peculiarly democratic arguments, Wahid refused to join ICMI since he viewed its establishment as leaning towards sectarianism and exclusivist. He believed that intellectuals should not organize themselves based on narrow categories like Islamic faith, since they gave the impression of being too eager to monopolize all social and political functions in the country. In this sense, Wahid's resistance to subordination to the state and his demand for the inclusion of all citizens into national political structures pointed to democratization.

In response to Wahid, some prominent figures of ICMI contended that the new organization was the most appropriate and effective means to serve the Muslim community and to seek greater democratization in Indonesia. For many ICMI activists, the existence of ICMI provided the opportunity to advance the cause of Islam and to realize an Islamic society. They also argued that the organization could be an effective means of advocating the creating a robust civil society by "de-militarizing" Indonesian politics. Adi Sasono, General Secretary of ICMI since 1995, for example, argued that the key issues

\footnotetext{
${ }^{58}$ Effendy, "Islam and the State," pp. 165-166.

59 On Wahid's political thoughts, see Mujiburrahman, "Islam and Politics in Indonesia: The Political Thought of Abdurrahman Wahid", Islam and Christian-Muslim Relations, vol. 10, no.3, 1999. pp. 339-352; Cf. also Ramage, Politics in Indonesia, particularly chapter 2 .
} 
for ICMI were democratization and an eventual reduction in the military's political role. He explained that a more democratic society would mean a reduction in the military's political role. ${ }^{60}$

Besides their different views of democratization, they differed in how they thought Islam-state relations should be like. According to Dawam Rahardjo, vice-chairman of the Experts Board of ICMI, the integration of the state and Muslim community was the underpinning for the process of democratization, because with such integration no obstacle existed any longer for Muslim participation in modernity and development. ${ }^{61}$ Meanwhile, Wahid was emphatic that the power of the government should never be used either on behalf of or against any particular religion. ${ }^{62}$ It is clear that Rahardjo merely pointed to the Muslim community as the majority; while Wahid pointed to all citizens without discrimination or privilege. With respect to the categories outlined in this study, the different opinions above indicate both 'formalist democracy' (ICMI activists) and 'subtantialist democracy' (Wahid).

Based on the above, I think, the substantial interpretation or 'substantialist democracy' is more compatible with genuine democracy than the formalistic interpretation or 'formalist democracy'. In this case, Aly's viewpoint appropriately portrayed the failure of 'formalist democracy' to accelerate the process of democratization in Indonesia. According to him, the foundation of ICMI unofficially institutionalized the unity of Islam and the state, which barred the way to a vigorous civil society and more democratization in Indonesia. ${ }^{63}$ By saying so, Aly was not actually criticizing ICMI, but rather expressing his hope of seeing ICMI become the pioneer of democratization in Indonesia. Unfortunately, far from striving to craft a democracy, ICMI failed even to object to the banning of the press by the new Order regime in 1994, which clearly contradicted a principal tenet of democracy: freedom of

\footnotetext{
${ }^{60}$ Ramage, Politics in Indonesia, pp. 96-97, 114. Actually I was eager to explain in depth the contemporary political debate between ICMI and its effort of democratization and Abdurrahman Wahid's effort on the same subject. Increasingly, this debate involves the discourse of civil society. However, this lies beyond the scope of this paper.

${ }^{61}$ Dawam Rahardjo, "Responsi ICMI terhadap Aspirasi Kerakyatan" paper presented in ICMI National Conference, Jakarta, 9 September 1995. p. 10.

62 Ramage, Politics in Indonesia, p. 62.

${ }^{63}$ Aly, "Keharusan Demokratisasi", pp. 141-2.
} 
the press. This may show us the dilemmas of a 'formalist democracy' close to the seat of power.

\section{Conclusion}

It may be said that the two different emphases on democracy above parallel the debate among scholars of democratization, which Huntington referred to, between the 'crafting' camp versus 'preconditions' camp. According to Huntington, the former held that democratization was primarily the product of political actors who have the will and the skill to bring it about; the latter argued that movement towards democracy depended on the existence of particular social, economic, or cultural preconditions. ${ }^{64}$

From this perspective, 'formalist democracy' is similar to the crafting camp while 'substantialist democracy' parallels the preconditions camp. Within an Indonesian context, the debate between the crafting and preconditions camps represented a dichotomy in the appreciation of the factors within Islam that work for and against democracy. The crafting camp seems to ignore certain preconditions: it believes that since Islam has the elements that make for democracy, the ideal condition of democracy may be crafted later.

On the other hand, the preconditions camp seems unconvinced that the factors within Islam could successfully work for democracy, because some factors inherent in Islam may preclude democracy. Accordingly, it is inclined to begin with a reinterpretation of Islamic doctrine in order to reconcile it with democratization (recasting and expanding the traditional doctrine regarding the status dhimmi $\gg \mathrm{f}$ nonMuslim minorities), and then demanding certain preconditions, like the guarantee that all human beings be treated equally, and there be nondiscrimination.

A significant lesson from the Indonesian discourses on democracy is as follows. If the ideal conditions of "Islamic democracy" are to be constructed, it would attempt to reinterpret the factors within Islam that stand against democracy. As long as this is never realized in Muslim countries, the promotion of a democratic process in the Muslim world may pose only risks and may lead, as Esposito says, to

${ }^{64}$ Huntington, "Democracy For The Long Haul", p. 4. 
the "hijacking of democracy" by Islamic fundamentalist groups committed to antidemocratic ideologies at the centre of power. ${ }^{65}$

Another important point is that "Islamic democracy" in Muslim countries is better posited as a complement, not an alternative, to what we may call genuine democracy, as practised in many democratic countries. This is critical, having become a determining factor of whether Islam-democracy relations are compatible or not. And finally, to put "Islamic democracy" in complementary position eventually will prove that democracy is universalizable, thus, confirm that Islam is a universal religion.]

\section{Bibliography}

Abdillah, Masykuri. Responses of Indonesian Muslim Intellectuals to the Concept of Democracy. Hamburg: Abera Network Austronesia, 1997.

Affandi, Arief. Islam Demokrasi Atas Bawab: Polemik Strategi Perjuangan Umat Model Gus Dur dan Amien Rais [Democratic Islam from within and below]. Yogjakarta: Pustaka Pelajar, 1996

Aly, Fachry. "Keharusan Demokratisasi dalam Islam Indonesia." In Nasrullah A. Fauzi (ed.), ICMI: Antara Status Quo dan Demokratisasi [ICMI: Between Status Quo and Democratization]. Bandung: Mizan, 1995.

Boland, B.J. The Struggle of Islam in Modern Indonesia. The Hague: Martinus Nijhoff, 1982.

Brown, Douglas M. Towards a Radical Democracy: The Political Economy of the Budapest School. London: Unwin Hyman, 1988.

Van Bruinessen, M., "State-Islam Relations in contemporary Indonesia; 1915-1990." In C. van Dijk and A. H. de Groot (eds.), State and Islam. Leiden: Research School CNWS, 1995.

\footnotetext{
${ }^{65}$ Esposito, The Islamic Threat: Myth or Reality?, p. 241. Huntington also points to this as a second potential threat to third-wave democracies. Cf. Huntington, "Democracy For The Long Haul”, pp. 8-9. With respect to the Indonesian context, Wahid has warned about this, implying that what happened to Algeria in 1992 may also occur in Indonesia. In his letter to President Soeharto, he says that Indonesia's political future may end up in chaos like that which took place in Algeria. That is, there may be an attempt to establish an Islamic state in place of the current Indonesian state. Cf. Ramage, Politics in Indonesia, p. 67.
} 
Effendy, Bahtiar. "Islam and the State: The Transformation of Islamic Political Ideas and Practices in Indonesia," Ph.D. Dissertation. The Ohio State University, 1994.

Esposito, John L. The Islamic Threat: Myth or Reality? New York Oxford: Oxford University Press, 1999.

George, Kenneth. "Designs on Indonesia's Muslim Communities", The Journal of Asian Studies, vol. 57, no. 3 (August 1998).

Hassan, Muhammad Kamal. Muslim Intellectual Responses to "New Order" Modernization in Indonesia. Kuala Lumpur: Dewan Bahasa dan Pustaka Kementrian Pelajaran Malaysia, 1982.

Hefner, Robert W. "Islamization and Democratization in Indonesia." In Robert W. Hefner and Patricia Horvatich (eds.), Politics and Religious Renewal in Muslim Southeast Asia. Honolulu: University of Hawaii Press, 1997.

Hefner, Robert. "Islam, State, and Civil Society: ICMI and the Struggle for the Indonesian Middle Class, Indonesia, no. 56 (1993).

Huntington, Samuel P. "Democracy for the Long Haul", Journal of Democracy, vol. 7, no. 2. (2 April 1996).

Karim, M. Rusli. Perjalanan Partai Politik Indonesia. Jakarta: Rajawali Press, 1983.

Liddle, William. "The Islamic Turn in Indonesia: A Political Explanation." Journal of Asian Studies, vol. 55, no. 3, August 1996.

Linz, Juan J. and Alfred Stepan. Problems of Democratic Transition and Consolidation: Southern Europe, South America and Post-Communist Europe. Baltimore and London: The Johns Hopkins University Press, 1996.

Madjid, Nurcholish, "Cita-cita Politik Kita", in Bosco Carvallo and Dasrizal (eds.). Aspirasi Umat Islam Indonesia. Jakarta: Leppenas, 1983.

Madjid, Nurcholish. "The Necessity of Renewing Islamic Thought and Reinvigorating Religious Understanding." In Charles Kurzman (ed.), Liberal Islam: A Sourcebook. New York: Oxford University Press, 1988. 
Ma'arif, A. Syafii. "Islam as the Basis of State: A Study of the Islamic Political Ideas as Reflected in the Constituent Assembly Debates in Indonesia," unpublished Ph.D. Dissertation, Illinois: University of Chicago, 1983.

Mujiburrahman, "Islam and Politics in Indonesia: The Political Thought of Abdurrahman Wahid", Islam and Christian-Muslim Relations, vol. 10, no.3 (1999).

Nasution, Adnan Buyung. The Aspiration for Constitutional Government in Indonesia: A Socio-legal Study of the Indonesian Konstituante 19561959. Jakarta: Pustaka Sinar Harapan, 1992.

Noer, Deliar. Pengantar Ke Pemikiran Politik. Jakarta: Rajawali Press, 1983.

Pinkney, Robert. Democracy in the Third World. Boulder, Colorado: Lynne Rienner Publishers, 1994.

Price, Daniel E. Islamic Political Culture, Democracy and Human Rights: A Comparative Study. Westport, Connecticut: Praeger, 1999.

Rahardjo, Dawam. "Responsi ICMI terhadap Aspirasi Kerakyatan" paper presented in ICMI National Conference, Jakarta, 9 September 1995.

Ramage, Douglas. Politics in Indonesia: Democracy, Islam and the Ideology of Tolerance. London and New York: Routledge, 1995.

Sulaiman, Sadek J. “Democracy and Shura." In Charles Kurzman (ed.), Liberal Islam: a Sourcebook (New York: Oxford University Press, 1998)

Syamsuddin, Sirajuddin. "Religion and Politics in Islam: The Case of Muhammadiyah in Indonesian New Order", Ph.D. Dissertation. Los Angeles, University of California, 1991 